
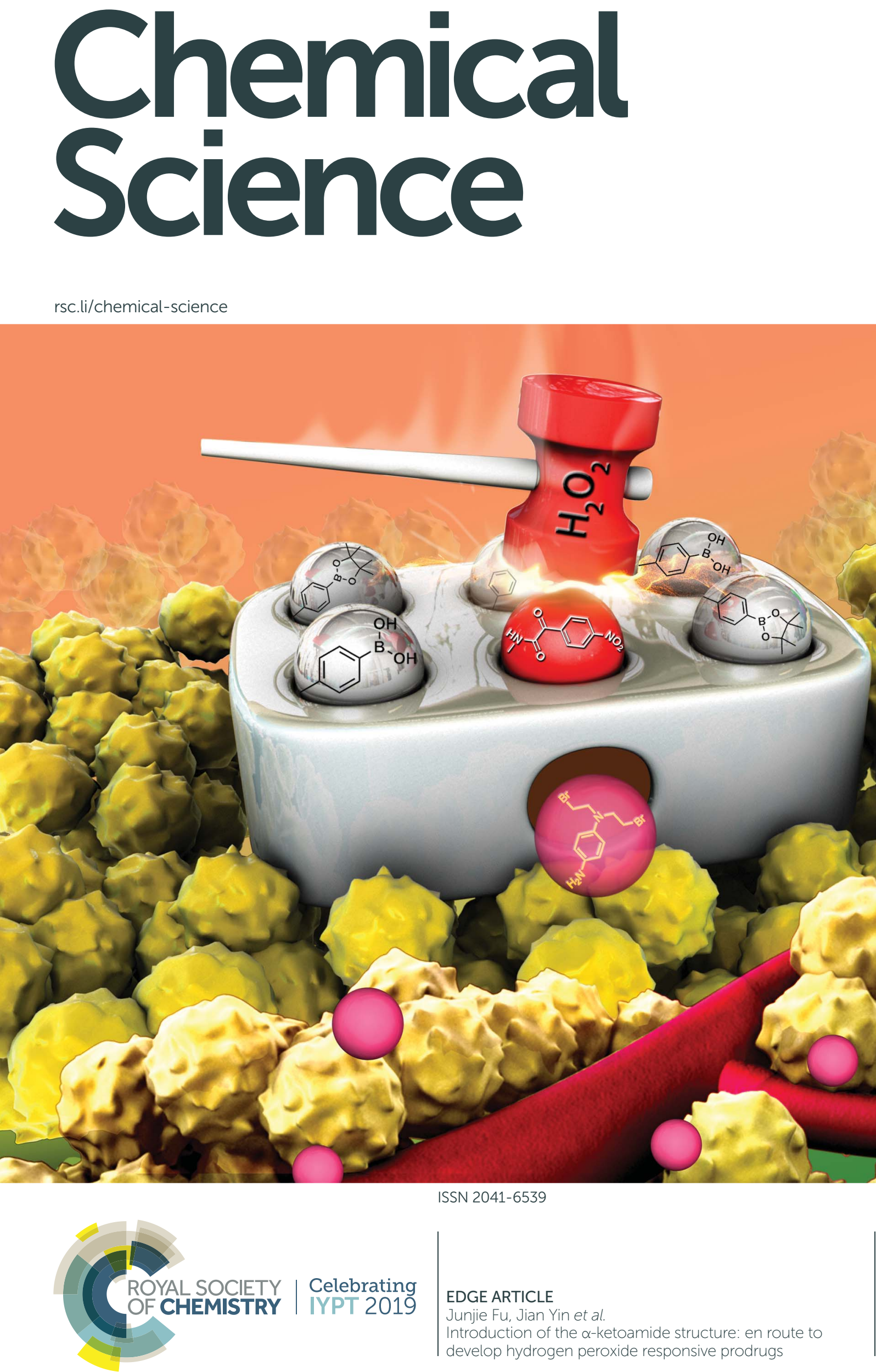
Check for updates

Cite this: Chem. Sci., 2019, 10, 7156

๑ All publication charges for this article have been paid for by the Royal Society of Chemistry

Received 21st February 2019

Accepted 28th June 2019

DOI: $10.1039 / \mathrm{c9sc00910h}$

rsc.li/chemical-science

\section{Introduction of the $\alpha$-ketoamide structure: en route to develop hydrogen peroxide responsive prodrugs $\dagger$}

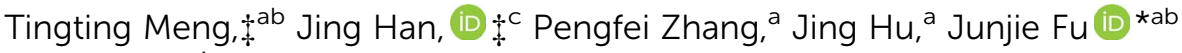 \\ and Jian Yin*a
}

Leveraging the elevated levels of hydrogen peroxide $\left(\mathrm{H}_{2} \mathrm{O}_{2}\right)$ in cancer, inflammatory diseases and cardiovascular disorders, $\mathrm{H}_{2} \mathrm{O}_{2}$-activated promoieties have been widely used in drugs and biomaterials design. However, the overwhelming majority of the promoieties only share the common structure of a $\mathrm{H}_{2} \mathrm{O}_{2}$-responsive arylboronic acid/ester moiety with low diversity. We report here an unprecedented strategy to construct novel $\mathrm{H}_{2} \mathrm{O}_{2}$-responsive prodrugs based on an $\alpha$-ketoamide structure. As a proof of concept, we designed and synthesized a panel of $\alpha$-ketoamide based nitrogen mustard prodrugs, among which KAM-2 showed potent growth inhibitory activity and high selectivity toward cancer cells. The $\mathrm{H}_{2} \mathrm{O}_{2}$-trigged decomposition of KAM-2 was validated, and the DNA damaging and apoptosis promoting activity attributed to the released nitrogen mustard were demonstrated. Our work unveils $\alpha$-ketoamide as a new scaffold for prodrug design and may quickly inspire future developments.

\section{Introduction}

Prodrugs and probes, two important and vibrant research subjects in medicinal chemistry and analytical chemistry, are indeed closely related. Probes are usually trigged by specific analytes to release fluorescent signals, and prodrugs are activated by pathological stimuli to liberate drugs. ${ }^{\mathbf{1 , 2}}$ Importantly, chemists are always encouraged by the analyte-responsive moieties of probes and expand their applications to prodrug design to achieve spatiotemporal control of drug release. Recent examples include the intriguing discoveries of prodrugs activated by $\beta$-secretase, ${ }^{3}$ histone deacetylase (HDAC)/cathepsin $\mathrm{L}$ (CTSL), ${ }^{4}$ matrix metalloproteinase-7 (MMP-7), ${ }^{5}$ caspase- $3,{ }^{6}{ }^{-}$ glutamyl transferase, ${ }^{7}$ thioredoxin reductase, ${ }^{8}$ lysyloxidase, ${ }^{9}$ photocleavage, ${ }^{10}$ hypochlorous acid,${ }^{11}$ etc.

$\mathrm{H}_{2} \mathrm{O}_{2}$ has been taken as an important molecule due to its elevated levels in many pathological conditions. ${ }^{12,13}$ The pioneer work from Chang et al., ${ }^{\mathbf{1 4}, \mathbf{1 5}}$ who initiated fluorescent probes bearing a $\mathrm{H}_{2} \mathrm{O}_{2}$-responsive boronate trigger in 2004-2005, led to the rapid expansion of this strategy to the design of $\mathrm{H}_{2} \mathrm{O}_{2}$ -

${ }^{a}$ Key Laboratory of Carbohydrate Chemistry and Biotechnology, Ministry of Education, School of Biotechnology, Jiangnan University, Wuxi 214122, P. R. China.E-mail:jfu@ jiangnan.edu.cn; jianyin@jiangnan.edu.cn

${ }^{b}$ School of Pharmacy, Nanjing Medical University, Nanjing 211166, P. R. China

${ }^{c}$ School of Chemistry \& Materials Science, Jiangsu Key Laboratory of Green Synthetic Chemistry for Functional Materials, Jiangsu Normal University, Xuzhou 221116, P. R. China

$\dagger$ Electronic supplementary information (ESI) available. See DOI: 10.1039/c9sc00910h

\$ These authors contributed equally. activated prochelators and MMP proinhibitors. ${ }^{16,17}$ Given the significantly high $\mathrm{H}_{2} \mathrm{O}_{2}$ concentrations $(5-1000 \mu \mathrm{M})$ in cancer cells relative to normal cells (0.001-0.7 $\mu \mathrm{M})$, Peng et al. ${ }^{18}$ for the first time, reported boron-based nitrogen mustard precursors as selective anticancer agents in 2011, followed by the blooming of various prodrugs (over 50 published papers) bearing an arylboronic acid/ester as the $\mathrm{H}_{2} \mathrm{O}_{2}$-cleavable trigger between 20122019 (Table $\mathrm{S} 1 \dagger$ ). Other $\mathrm{H}_{2} \mathrm{O}_{2}$-responsive moieties, such as arylsulfonyl ester, ${ }^{19}$ thiazolidinone, ${ }^{20}$ and benzothiazole ${ }^{21}$ have also been reported for constructing small molecule prodrugs, but with very limited examples of each. In addition, sulfide, thioether, thioketal, selenium, and peroxalate ester are also known as $\mathrm{H}_{2} \mathrm{O}_{2}$-sensitive scaffolds, but in most cases, their applications are confined to polymers or nanoparticles. ${ }^{22,23}$ As yet, currently over $90 \% \mathrm{H}_{2} \mathrm{O}_{2}$-activated small molecule prodrugs still rely on the long-known boron-based triggers. Moreover, several disadvantages have been reported for the boron moiety, such as the high susceptibility of boronic esters to hydrolysis, ${ }^{24}$ the off-target reactions between boronic acids and biological diols, ${ }^{25}$ the moderate selectivity toward $\mathrm{H}_{2} \mathrm{O}_{2}$ and interference from $\mathrm{ONOO}^{-}$, as well as the potential unknown bioeffects from the by-produced boric acid. ${ }^{21}$ Considering the extremely low structural diversity of the current $\mathrm{H}_{2} \mathrm{O}_{2}$-responsive prodrugs, we have been highly interested in searching for novel chemical structures with $\mathrm{H}_{2} \mathrm{O}_{2}$-cleavable property.

We were recently enlightened by the elegant work from Tang et al., who used $\alpha$-ketoamide-based fluorescent probes for intracellular $\mathrm{H}_{2} \mathrm{O}_{2}$ visualization. ${ }^{26-28}$ The $\alpha$-ketoamide moiety was demonstrated as a highly specific reaction switch for $\mathrm{H}_{2} \mathrm{O}_{2}$. Herein, as a proof-of-concept, we introduce the $\alpha$-ketoamide 
group into prodrug design by hybridizing it with nitrogen mustards, affording a panel of $\alpha$-ketoamide-based nitrogen mustard (KAM) prodrugs. Multiple assays confirmed that one of the prodrugs, KAM-2, was efficiently and preferentially activated by $\mathrm{H}_{2} \mathrm{O}_{2}$, and showed potent and selective cytotoxicity to several cancer cell lines, particularly for HL-60 human leukemia cells. The ability of KAM-2 to induce DNA damage and apoptosis was thoroughly studied. To the best of our knowledge, this is the first example to utilize the $\alpha$-ketoamide moiety as an alternative non-boron $\mathrm{H}_{2} \mathrm{O}_{2}$-responsive element for prodrug development.

\section{Results and discussion}

\section{Design and synthesis of KAM prodrugs}

The structures of KAM prodrugs are illustrated in Scheme 1. It is speculated that the $\alpha$-ketoamide moiety in KAM-1-KAM-4 acts as an electron-withdrawing group and shields the activity of nitrogen mustards. ${ }^{18,29-31}$ Upon the nucleophilic attack by $\mathrm{H}_{2} \mathrm{O}_{2}$ anion and the following Baeyer-Villiger rearrangement, ${ }^{27}$ the promoiety finally hydrolyses into aniline nitrogen mustards with increased nitrogen electron density and restored DNA alkylating activity. To enrich the structural diversity, quaternary ammonia salts KAM-5 and KAM-6 were also designed as masked mustard prodrugs. The activation process of KAM-5 and KAM-6 are similar to the mechanism described above but require an additional spontaneous 1,6-elimination. ${ }^{32}$

The synthetic route (Scheme 2) of the target compounds commenced with a $\mathrm{SeO}_{2}$-mediated oxidation of acetophenone in pyridine to afford phenylglyoxylic acid $\mathbf{1}$, which was coupled with $\mathrm{N}$-4-aminophenyl-diethanolamine or (4-aminophenyl) methanol in the presence of EDCI and DIEA to give $\alpha$-ketoamides 2 or 3 , respectively. The two hydroxy groups of 2 were methylated to generate KAM-3. Further dichlorination, dibromination, and monochlorination of KAM-3 furnished KAM-1, KAM-2, and KAM-4, respectively. Bromination of the hydroxy

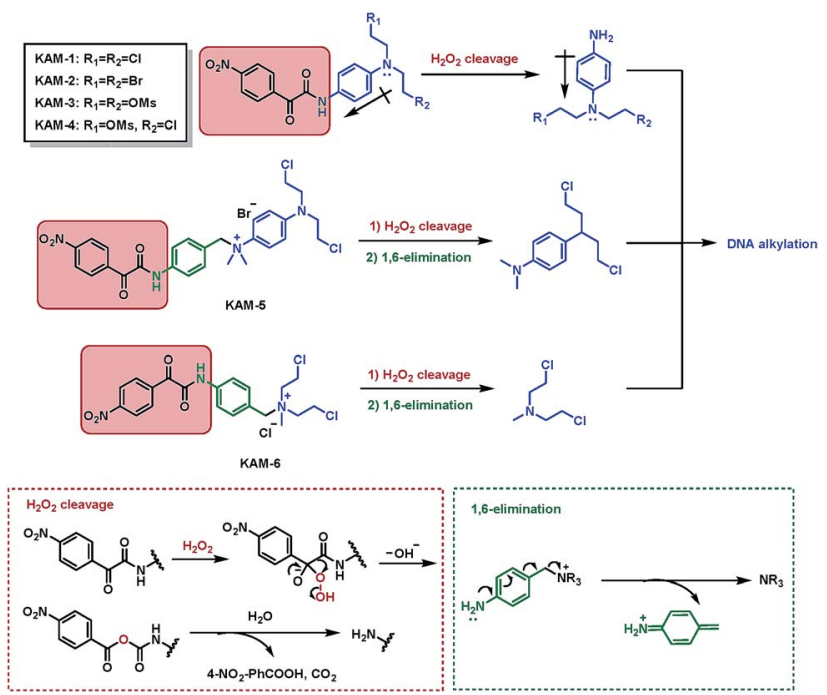

Scheme 1 Structures of KAM prodrugs and the mechanisms of $\mathrm{H}_{2} \mathrm{O}_{2}$ responsive activation to generate DNA alkylating agents.

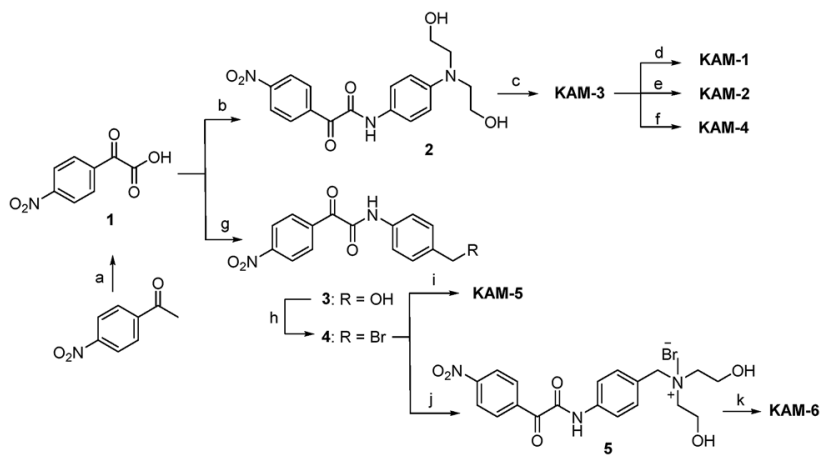

Scheme 2 Synthesis of KAM prodrugs. Reactants and conditions: (a) $\mathrm{SeO}_{2}$, pyridine, $90{ }^{\circ} \mathrm{C}, \mathrm{N}_{2}, 35 \%$; (b) N-4-aminophenyl diethanolamine, EDCl, DIEA, DMF, 42\%; (c) MsCl, DMAP, TEA, DCM, reflux, 70\%; (d) LiCl (5 eq.), DMF, $60{ }^{\circ} \mathrm{C}, 65 \%$; (e) $\mathrm{NaBr}$ (5 eq.), DMF, $60{ }^{\circ} \mathrm{C}, 67 \%$; (f) $\mathrm{LiCl}(1$ eq.), $\mathrm{MeCN}, 60{ }^{\circ} \mathrm{C}, 23 \%$; (g) (4-aminophenyl)methanol, EDCl, DIEA, $\mathrm{DMF}, 33 \%$; (h) $\mathrm{CBr}_{4}, \mathrm{PPh}_{3}, \mathrm{DCM}, 0{ }^{\circ} \mathrm{C}-$ r.t., $50 \%$; (i) $\mathrm{N}$-(4- $\mathrm{N}^{\prime}, \mathrm{N}^{\prime}$-dimethylaminophenyl)-bis(2-chloroethyl)amine, $\mathrm{MeCN}, 43 \%$; (j) $\mathrm{N}$-methyldiethanolamine, $\mathrm{CHCl}_{3}$, reflux, $76 \%$; (k) $\mathrm{SOCl}_{2}$, r.t., $62 \%$.

group of 3 using $\mathrm{CBr}_{4}$ and $\mathrm{PPh}_{3}$ yielded 4 , which was then directly reacted with aniline nitrogen mustard to give KAM-5. Alternatively, nucleophilic substitution of $\mathbf{4}$ with $\mathrm{N}$-methyldiethanolamine, followed by chlorination with $\mathrm{SOCl}_{2}$ generated KAM-6. Detailed synthetic procedures and spectroscopic data are provided in the ESI. $\dagger$

\section{Anticancer activity screening}

The antiproliferative activity of KAM prodrugs was screened against four human cancer cell lines (A549, HepG2, HCT-116, and HL-60), which have all been well-employed in $\mathrm{H}_{2} \mathrm{O}_{2}$ responsive prodrug studies. ${ }^{33-35}$ The classical nitrogen mustard mechlorethamine (MEC) was selected as the positive control. Evidently, KAM-2 exhibited the most potent activity among all the candidates (Fig. 1). At a dose of $10 \mu \mathrm{M}$, the inhibition rates of KAM-2 in all cancer cells were $>50 \%$, which further exceeded $80 \%$ at $20 \mu \mathrm{M}$. Structurally similar prodrugs KAM-3 and KAM-4 showed decreased cytotoxicity compared with KAM-2. The activity of chlorine counterpart, KAM-1, was further compromised. These results suggest that the leaving groups of mustard significantly affect the anticancer activity of KAM prodrugs. Ammonia salts KAM-5 and KAM-6 showed limited inhibition effects, particularly for KAM-5, possibly due to their lower membrane permeability and absorption. ${ }^{30}$ This assumption was preliminarily tested by calculating the $\log P$ and membrane permeability values of KAM prodrugs, and the results are summarized in Table S2. $\dagger$ Considering the essential role of the nitro group of KAM in $\mathrm{H}_{2} \mathrm{O}_{2}$-initiated nucleophilic attack, ${ }^{26,27}$ a non-nitro analogue KAM-7 was synthesized (ESI $\dagger$ ) as a negative control, which was supposed to be resistant to $\mathrm{H}_{2} \mathrm{O}_{2}$. As expected, KAM-7 displayed diminished cytotoxicity against cancer cells (Fig. 1), demonstrating the role of $\mathrm{H}_{2} \mathrm{O}_{2}$ in prodrug activation.

The anticancer activity of KAM-2 was then more closely studied by measuring its $\mathrm{IC}_{50}$ values, employing three additional $\mathrm{H}_{2} \mathrm{O}_{2}$-overproducing cancer cell lines (SW620, MCF-7, 

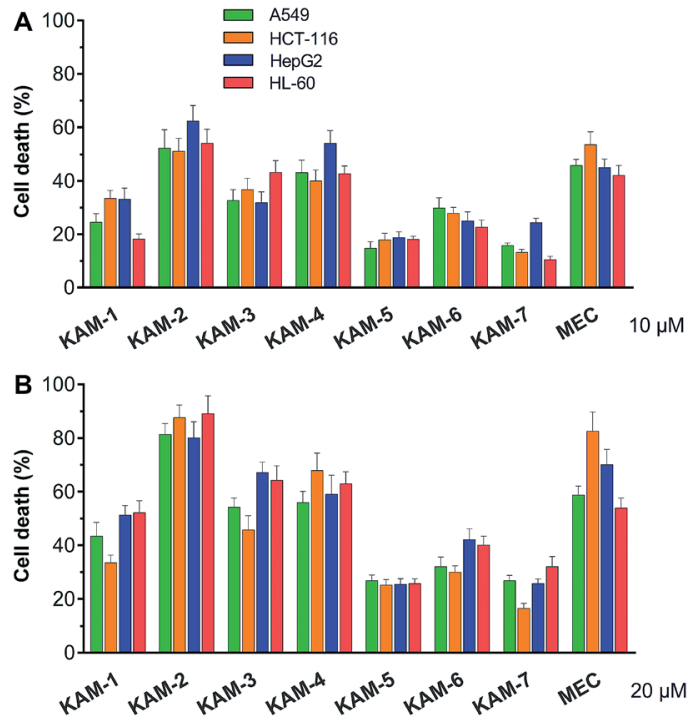

Fig. 1 Cytotoxicity of KAM prodrugs against four human cancer cell lines. Cells were incubated with indicated compounds at $10(A)$ and 20 $\mu M(B)$ for $72 h$, and the percentages of cell death were assessed by MTT and CCK- 8 assays. Mean \pm SD, $n=3$.

PANC-1 $)^{36-38}$ plus one normal line, peripheral blood mononuclear cell (PBMC) (Fig. S1 $\dagger$ ). As summarized in Table 1, KAM2 showed lower $\mathrm{IC}_{50}$ values than MEC in cancer cells, except for PANC-1, which was particularly sensitive to MEC. The lowest IC $_{50}(5.942 \mu \mathrm{M})$ of KAM-2 was seen in HL-60 cell. Encouragingly, KAM-2 proved its excellent selectivity toward cancer cells since the $\mathrm{IC}_{50}$ value in PBMC was larger than $50 \mu \mathrm{M}$. In contrast, MEC remained cytotoxic in PBMC with an $\mathrm{IC}_{50}$ value of $11.50 \mu \mathrm{M}$.

\section{$\mathrm{H}_{2} \mathrm{O}_{2}$-responsive behaviours}

All the KAM prodrugs decomposed quickly upon $\mathrm{H}_{2} \mathrm{O}_{2}$ treatment (Fig. S2A †). Considering the good cytotoxicity and selectivity of KAM-2 toward cancer cells, its $\mathrm{H}_{2} \mathrm{O}_{2}$-responsive behaviours were in-depth studied. KAM-2 exhibited a decent stability in the absence of $\mathrm{H}_{2} \mathrm{O}_{2}$ at $\mathrm{pH} 4,7,10$, respectively

Table $1 \quad \mathrm{CC}_{50}$ values $(\mu \mathrm{M})$ of KAM-2 and MEC against selected cell lines $^{a}$

\begin{tabular}{lrr}
\hline & \multicolumn{1}{c}{$\mathrm{IC}_{50}(\mu \mathrm{M})$} & \\
\cline { 2 - 3 } Cell lines & \multicolumn{1}{c}{ KAM-2 } & \multicolumn{1}{c}{ MEC } \\
\hline A549 & $8.82 \pm 0.83$ & $10.07 \pm 0.71$ \\
HCT-116 & $8.01 \pm 0.85$ & $13.25 \pm 1.57$ \\
HepG2 & $8.84 \pm 1.24$ & $10.68 \pm 1.52$ \\
HL-60 & $5.94 \pm 0.94$ & $12.60 \pm 3.47$ \\
MCF-7 & $12.19 \pm 1.55$ & $24.26 \pm 1.23$ \\
PANC-1 & $16.25 \pm 1.15$ & $2.19 \pm 0.08$ \\
SW620 & $9.10 \pm 0.27$ & $18.50 \pm 0.07$ \\
PBMC & $>50$ & $11.50 \pm 0.94$
\end{tabular}

${ }^{a}$ Cells were incubated with indicated compounds at different concentrations for $72 \mathrm{~h}$, and IC $_{50}$ values were measured by MTT and CCK-8 assays. Mean \pm SD, $n=3$.
(Fig. S2B and $\mathrm{S} 2 \mathrm{C} \dagger$ ). $\mathrm{H}_{2} \mathrm{O}_{2}$ rapidly trigged the decomposition of KAM-2 in a $\mathrm{H}_{2} \mathrm{O}_{2}$ equivalent-dependent way (Fig. S2D $\dagger$ ). As monitored by HPLC, the released nitrogen mustard $N, N$-bis(2bromoethyl)benzene-1,4-diamine (BrM), as well as the byproduct $p$-nitrobenzoic acid (PNB), were clearly observed 60 min after $\mathrm{H}_{2} \mathrm{O}_{2}$ treatment (Fig. 2A). In sharp contrast, KAM-7 remained intact regardless of $\mathrm{H}_{2} \mathrm{O}_{2}$ presence (Fig. 2B and $\mathrm{S} 2 \mathrm{E} \dagger$ ). The decomposition of KAM-2 in $\mathrm{H}_{2} \mathrm{O}_{2}$ was further studied by ${ }^{1} \mathrm{H}$ NMR and mass spectroscopy, both of which unambiguously confirmed the prodrug activation behaviour (Fig. S3 and $\mathrm{S} 4 \dagger$ ). It is worth noting that in both HPLC and NMR studies, the signal of BrM shrank with time and became barely visible after long time treatment with $\mathrm{H}_{2} \mathrm{O}_{2}$. This is highly possible due to the instability of the phenylenediamine mustard toward $\mathrm{H}_{2} \mathrm{O}_{2}$ oxidation ${ }^{39,40}$ under the in vitro study conditions, as shown in Fig. S5 and S6. $\dagger$ To provide a visual demonstration of the mustard release from KAM-2, BrM was prepared as a yellow solution, which turned dark upon $\mathrm{H}_{2} \mathrm{O}_{2}$ addition. The same colour change was observed with KAM-2/ $\mathrm{H}_{2} \mathrm{O}_{2}$, but not with KAM-7/ $\mathrm{H}_{2} \mathrm{O}_{2}$ (Fig. S7 $\dagger$ ). Moreover, in HL-60 cells, $\mathrm{H}_{2} \mathrm{O}_{2}$ scavenger $\mathrm{N}$-acetyl-cysteine (NAC) pretreatment remarkably decreased the cytotoxicity of KAM-2, but not KAM-7 (Fig. 2C). All the above results clearly demonstrated the $\mathrm{H}_{2} \mathrm{O}_{2}$ responsive activation of KAM-2. In regards of selectivity, KAM-2 was resistant to $\mathrm{HO}^{*},{ }^{t} \mathrm{BuO}^{\circ}$, TBHB, $\mathrm{NO}, \mathrm{GSH}$, and $\mathrm{Fe}^{2+}$, very stable in $\mathrm{ClO}^{-}$, Cys and Hcy. Slight decomposition was observed in $\mathrm{ONOO}^{-}$, but to a much lesser extent than in $\mathrm{H}_{2} \mathrm{O}_{2}$ (Fig. 2D).

\section{Proapoptotic mechanism of KAM-2}

The anticancer activity of KAM-2 was further evaluated in HL60 cells using MEC as positive control. It was found that KAM-2 treatment for $48 \mathrm{~h}$ induced apoptosis (Fig. 3A and S8A $\dagger$ ) of HL-60 cells in a dose-dependent manner. Notably, NAC
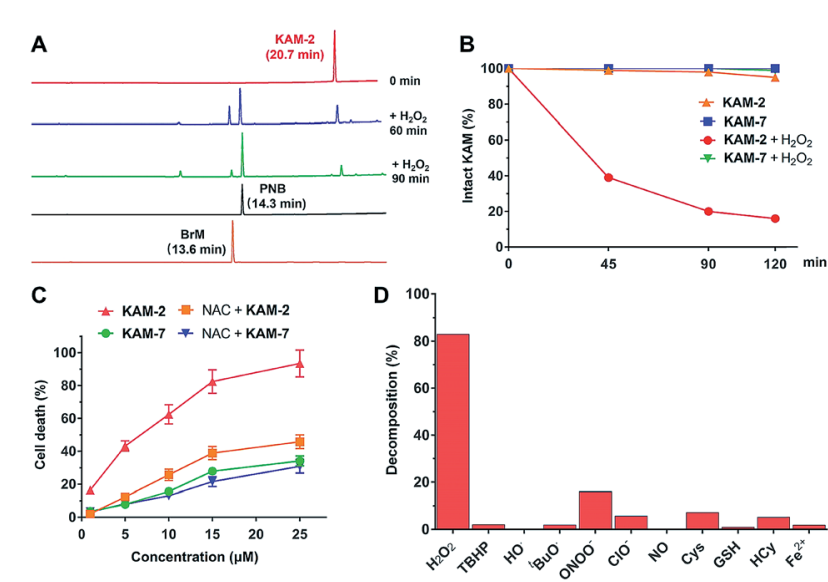

Fig. $2 \mathrm{H}_{2} \mathrm{O}_{2}$-responsive behaviours of KAM-2. (A) Decomposition of $100 \mu \mathrm{M} \mathrm{KAM}-2$ in presence of $\mathrm{H}_{2} \mathrm{O}_{2}$ (2 eq.) as monitored by RP-HPLC (254 nm). (B) Decomposition of KAM-2 and KAM-7 (100 $\mu \mathrm{M})$ with or without $\mathrm{H}_{2} \mathrm{O}_{2}$ (10 eq.). (C) The effects of NAC on the cytotoxicity of KAM-2 and KAM-7 in HL-60 cells after $72 \mathrm{~h}$ incubation. (D) Selectivity of KAM-2 toward $\mathrm{H}_{2} \mathrm{O}_{2}$ as determined by measuring its decomposition ratios under various stimuli. 

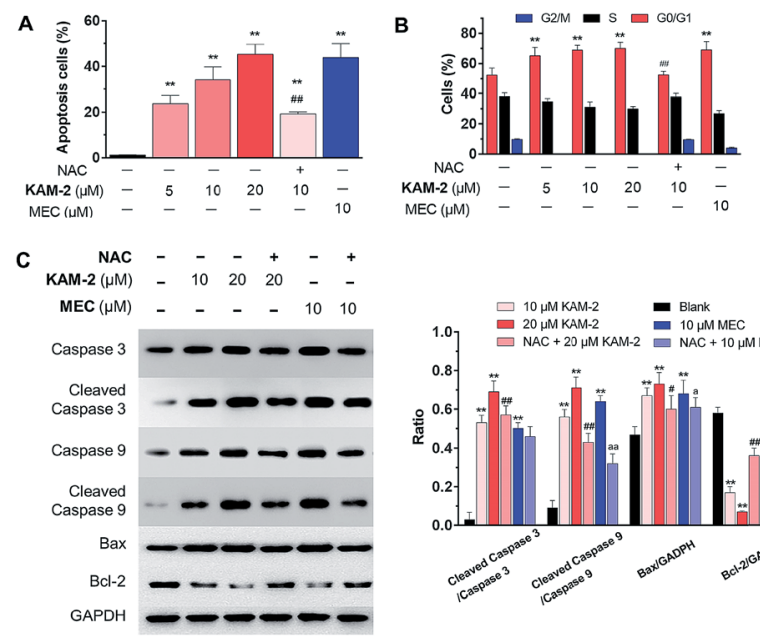

D
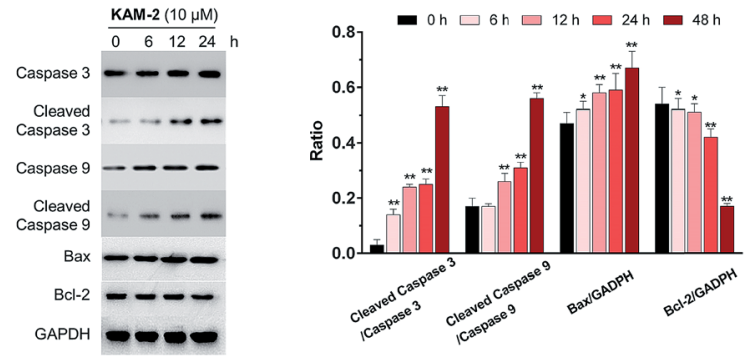

Fig. 3 (A) Apoptotic effects of KAM-2 measured by flow cytometry using annexin $\mathrm{V}$-FITC/PI staining. HL-60 cells were treated with compounds at indicated concentrations for $48 \mathrm{~h}$, or pre-incubated with ROS scavenger NAC ( $20 \mathrm{mM})$ for $1 \mathrm{~h}$, followed by treatment with $10 \mu \mathrm{M}$ KAM-2 for $48 \mathrm{~h}$. Mean $\pm \mathrm{SD}, n=3$. (B) Effects of KAM-2 on cell cycle arrest. HL-60 cells were treated with compounds at indicated concentrations for $48 \mathrm{~h}$, or pre-incubated with NAC (20 mM) for $1 \mathrm{~h}$, followed by treatment with $10 \mu \mathrm{M}$ KAM-2 for $48 \mathrm{~h}$. The percentage of cells in each cell cycle phase was analyzed by flow cytometry, mean \pm $\mathrm{SD}, n=3$. (C) Dose-dependent effects of KAM-2 on the expression of apoptosis-related proteins by Western blot. HL-60 cells were treated with compounds at indicated concentrations for $48 \mathrm{~h}$ or pre-incubated with NAC $(20 \mathrm{mM})$ for $1 \mathrm{~h}$, followed by treatment with compounds for $48 \mathrm{~h}$. Mean $\pm \mathrm{SD}, n=3 .{ }^{* *} p<0.01 \mathrm{vs}$. blank; ${ }^{*} p<0.05$ vs. 20 $\mu$ M KAM-2 treatment; ${ }^{\# \#} p<0.01$ vs. $20 \mu$ M KAM-2 treatment; ${ }^{a} p$ $<0.05$ vs. $10 \mu \mathrm{M}$ MEC treatment; ${ }^{a a} \mathrm{p}<0.01$ vs. $10 \mu \mathrm{M}$ MEC treatment. (D) Time-dependent effects of KAM-2 on the expression of apoptosisrelated proteins by Western blot. HL-60 cells were treated with $10 \mu \mathrm{M}$ KAM-2 for $0,6,12,24$, and $48 \mathrm{~h}$. Mean \pm SD, $n=3$. ${ }^{*} p<0.05 \mathrm{vs}$. $0 \mathrm{~h} ;{ }^{* *} p$ $<0.01$ vs. $0 \mathrm{~h}$

pretreatment significantly decreased the activity of KAM-2. Neither KAM-7 nor NAC showed apoptosis-inducing activity under the same condition (Fig. S8B $\dagger$ ). Moreover, KAM-2 arrested cell cycle in G0/G1 phase and NAC reversed the cell cycle arrest (Fig. 3B and S9†). Modest effects of KAM-2 on the loss of mitochondrial membrane potential were also observed (Fig. S10 $\dagger$ ). Western blot studies revealed that KAM-2 induced the cleavage of caspase 3 and caspase 9, elevated the expression of Bax, and suppressed the expression of Bcl-2 in a dose (Fig. 3C) and time (Fig. 3D) dependent way, similar to the effects of MEC. The above results suggest that KAM-2 acts at least partially through the mitochondria-mediated apoptosis pathway.

\section{DNA cross-linking and damaging effects of KAM-2}

In addition to the above disclosed mechanism, the nitrogen mustard released from KAM-2 upon $\mathrm{H}_{2} \mathrm{O}_{2}$ activation is supposed to exert its cytotoxicity by DNA interstrand crosslinking (ICL). ${ }^{41}$ This was first examined by a fluorescence quenching experiment. It is known that ethidium bromide (EB) interacts with DNA to yield maximum fluorescence emission at $600 \mathrm{~nm}\left(E_{\mathrm{x}}=300 \mathrm{~nm}\right)$, which is supposed to be quenched due to competitive binding of nitrogen mustard to DNA. As expected, KAM-2 decreased the fluorescence intensity at $600 \mathrm{~nm}$ in the presence of $\mathrm{H}_{2} \mathrm{O}_{2}$ (Fig. 4).

The DCL ability of activated KAM-2 was further confirmed by denaturing alkaline agarose gel electrophoresis. ${ }^{42}$ As shown in Fig. 5A and B, KAM-2 or $\mathrm{H}_{2} \mathrm{O}_{2}$ alone had no effects on linearized pBR322 plasmid DNA. However, in the presence of $10 \mathrm{mM}$ $\mathrm{H}_{2} \mathrm{O}_{2}$, KAM-2 treatment induced DNA ICL (from 3.3\% to 94.8\%) as indicated by the intensified bands of double strand DNA (dsDNA) in both a dose and time dependent way. In contrast, KAM-7 combined with $\mathrm{H}_{2} \mathrm{O}_{2}$ was unable to yield dsDNA (Fig. 5C). These results again, strongly support the $\mathrm{H}_{2} \mathrm{O}_{2}$-triggered activation of KAM-2 and consequent generation of nitrogen mustard.

Next, the DNA damaging activity of KAM-2 was assessed in HL-60 cells using comet assay. KAM-2 treatment resulted in obvious cellular DNA damage as visually shown in Fig. 6. NAC preincubation protected HL-60 cells from tail DNA formation due to diminished activation of KAM-2. KAM-7 or NAC alone had no effects on DNA damage (Fig. S11 $\dagger$ ).

Following DNA double-strand break (DSB), histone $\mathrm{H}_{2} \mathrm{AX}$ is rapidly phosphorylated at $\operatorname{Ser}_{139}$ to yield $\gamma-\mathrm{H}_{2} \mathrm{AX}$ as a golden biomarker of DNA damage response (DDR). ${ }^{43}$ The expression of $\gamma-\mathrm{H}_{2} \mathrm{AX}$ upon KAM-2 treatment was therefore examined using immunofluorescence microscopy. Incubation of HL-60 cells with KAM-2 for $12 \mathrm{~h}$ remarkably increased the level of $\gamma-\mathrm{H}_{2} \mathrm{AX}$ (Fig. 7). Notably, when KAM-2 was removed and cells were allowed to grow without KAM-2 for an additional 6 or $12 \mathrm{~h}$, elevated expression of $\gamma-\mathrm{H}_{2} \mathrm{AX}$ was still observed. However, NAC pretreatment mitigated the effects of KAM-2 on $\gamma-\mathrm{H}_{2} \mathrm{AX}$
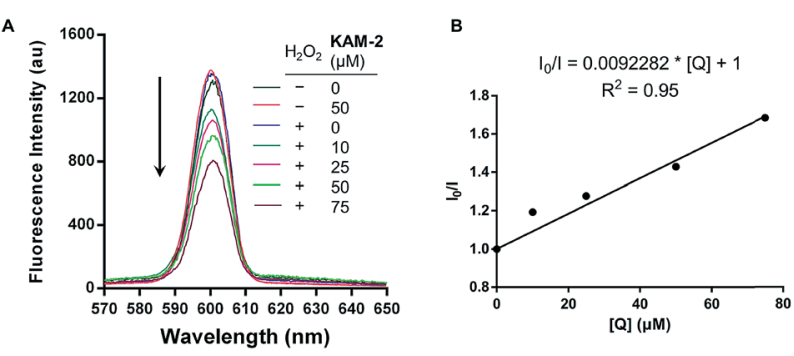

Fig. 4 (A) Fluorescence quenching of EB/DNA by KAM-2. Various concentrations of KAM-2 was added into EB-DNA solution $(2.5 \mu \mathrm{M}$ EB and $50 \mu \mathrm{M}$ linearized pBR322 plasmid DNA) with or without $\mathrm{H}_{2} \mathrm{O}_{2}(10$ $\mathrm{mM}$ ) in Tris- $\mathrm{HCl} / \mathrm{NaCl}$ buffer. $E_{\mathrm{x}}=300 \mathrm{~nm}$ (B) Stern-Volmer plots of fluorescence quenching of EB-DNA by KAM-2. $I_{0}$ and $/$ are the emission intensity in the absence and presence of the KAM-2, respectively. Slope $\left(K_{\mathrm{sv}}\right)$ is the quenching rate constant, and $[Q]$ is the concentration of the quencher KAM-2. 
A

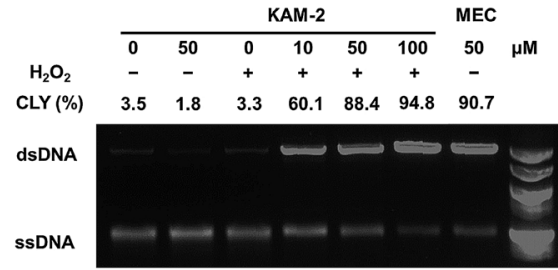

B

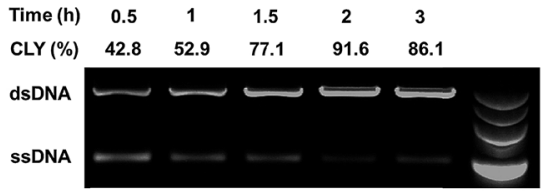

C

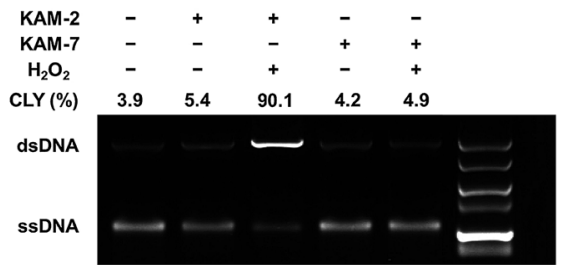

Fig. 5 DNA interstrand cross-linking (ICL) ability of KAM-2. (A) Denaturing alkaline agarose gel electrophoresis performed with $1 \mu \mathrm{g}$ linearized pBR322 plasmid DNA and indicated concentrations of KAM2 or $\mathrm{MEC}$ with or without $\mathrm{H}_{2} \mathrm{O}_{2}(10 \mathrm{mM})$ for $2 \mathrm{~h}$ at $37^{\circ} \mathrm{C}$. (B) Denaturing alkaline agarose gel electrophoresis performed with $1 \mu \mathrm{g}$ linearized pBR322 plasmid DNA, $50 \mu \mathrm{M} \mathrm{KAM}-2$, and $10 \mathrm{mM} \mathrm{H}_{2} \mathrm{O}_{2}$ at $37{ }^{\circ} \mathrm{C}$ for indicated time. (C) Denaturing alkaline agarose gel electrophoresis

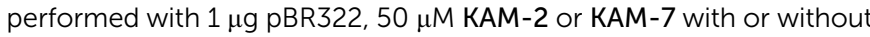
$\mathrm{H}_{2} \mathrm{O}_{2}(10 \mathrm{mM})$ for $2 \mathrm{~h}$ at $37^{\circ} \mathrm{C}$. CLY: cross-linking yield.

formation. Compared with KAM-2, KAM-7 and NAC had negliable effects on $\gamma-\mathrm{H}_{2} \mathrm{AX}$ formation as shown in Fig. S12. $\dagger$

In addition to $\gamma-\mathrm{H}_{2} \mathrm{AX}$, poly(ADP-ribose) polymerase- 1 (PARP1), RAD51 and BRCA1 are activated by DNA DSB and involved in DNA repair. ${ }^{44}$ The changes of PARP1, RAD51, BRCA1, and $\gamma-\mathrm{H}_{2} \mathrm{AX}$ were quantified by Western blot. Clearly, KAM-2 induced the cleavage of PARP1 and increased the expression of $\gamma-\mathrm{H}_{2} \mathrm{AX}$, RAD51 and BRCA1 in a dose (Fig. 8A) and
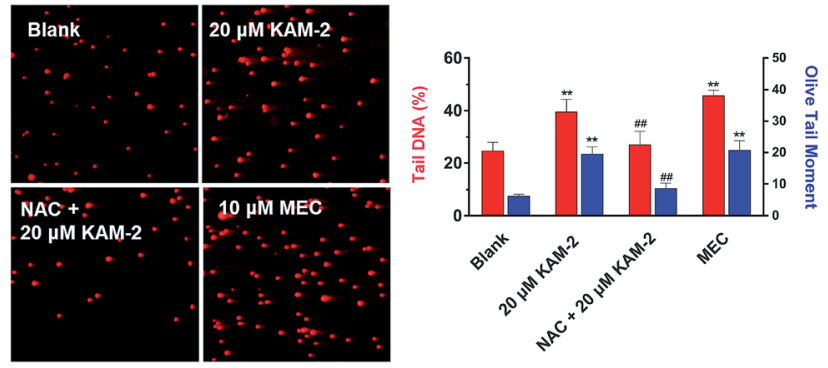

Fig. 6 Effects of KAM-2 on cell damage assessed by comet assay. HL60 cells were treated with $20 \mu \mathrm{M}$ KAM-2 or $10 \mu \mathrm{M}$ MEC for $48 \mathrm{~h}$, or pre-incubated with NAC $(20 \mathrm{mM})$ for $1 \mathrm{~h}$, followed by treatment with $10 \mu \mathrm{M}$ KAM-2 for $48 \mathrm{~h}$. Alkaline comet electrophoresis was performed. Quantitative analysis was conducted with the comet analysis software CASP. The tail DNA\% and olive tail moment were employed to evaluate DNA damage. Mean $\pm \mathrm{SD}, n=3 .{ }^{* *} p<0.01$ vs. blank; ${ }^{\# \#} p<0.01$ vs. 20 $\mu M$ KAM-2 treatment.

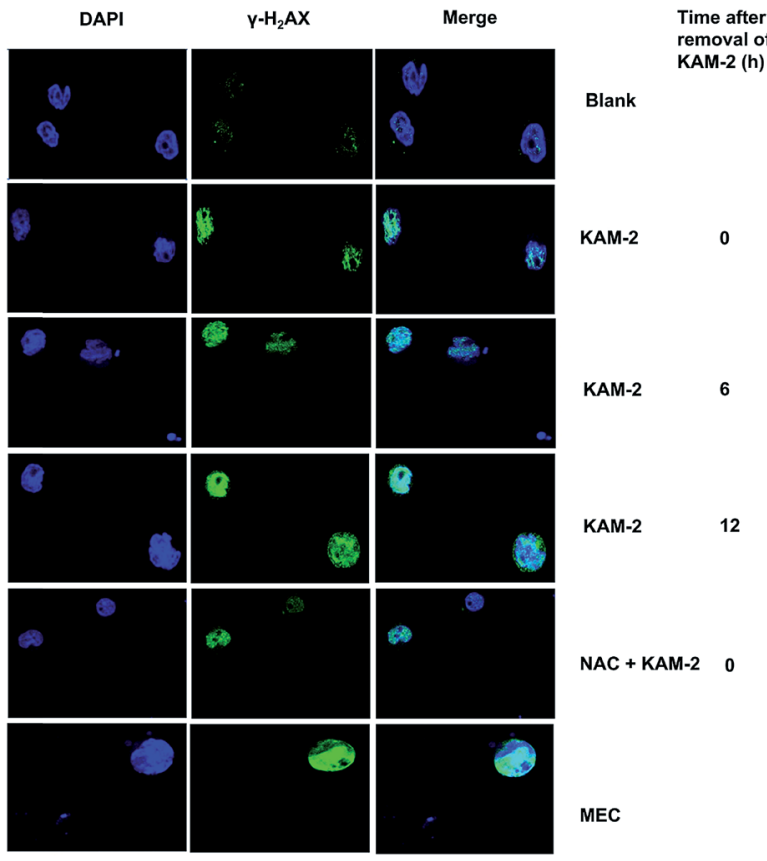

Fig. 7 Immunofluorescence of DNA cleavage protein $\gamma \mathrm{H}_{2} \mathrm{AX}$. HL-60 cells were treated with KAM-2 or MEC $(10 \mu \mathrm{M})$ for $12 \mathrm{~h}$, or pre-incubated with ROS scavenger NAC $(20 \mathrm{mM})$ for $1 \mathrm{~h}$, followed by treatment with KAM-2 for $12 \mathrm{~h}$. For some groups, cells were incubated for an additional 6 or $12 \mathrm{~h}$ after removal of KAM-2.

time (Fig. 8B) dependent way. In contrast, KAM-7 or NAC treatment led to no alterations of the expressions of cleaved PARP1 or $\gamma-\mathrm{H}_{2} \mathrm{AX}$ (Fig. S13 $\dagger$ ).
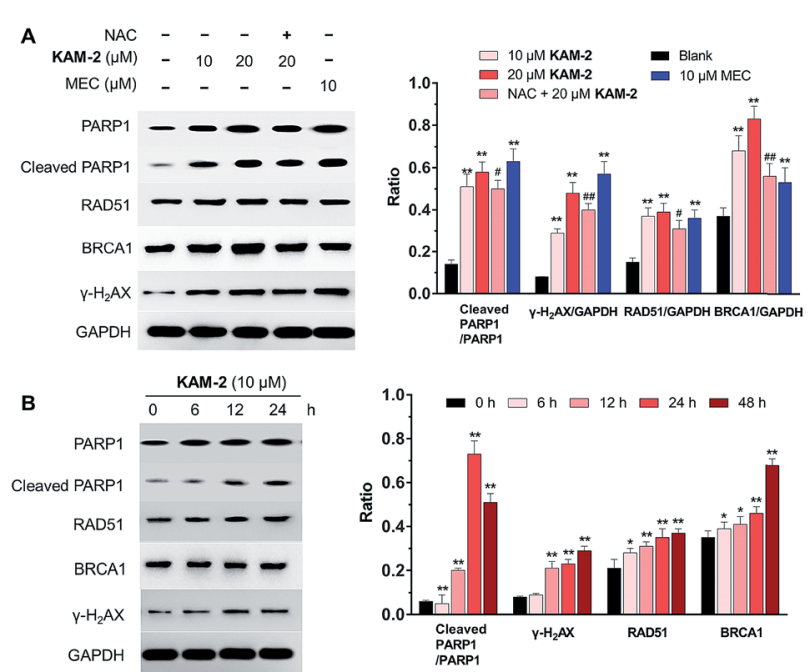

Fig. 8 (A) Concentration-dependent effects of KAM-2 on the expression of DDR-related proteins by Western blot. HL-60 cells were treated with compounds at indicated concentrations for $48 \mathrm{~h}$ or pre-incubated with NAC (20 mM) for $1 \mathrm{~h}$, followed by treatment with compounds for 48 h. Mean \pm SD,$n=3$. ${ }^{* *} p<0.01$ vs. blank; ${ }^{*} p<0.05$ vs. $20 \mu$ M KAM-2 treatment; ${ }^{\# \#} p<0.01$ vs. $20 \mu$ M KAM-2 treatment. (B) Time-dependent effects of KAM- 2 on the expression of DDR-related proteins by Western blot. HL-60 cells were treated with $10 \mu \mathrm{M} \mathrm{KAM-2} \mathrm{for} 0,6,12,24$, and 48 h. Mean \pm SD, $n=3$. ${ }^{*} p<0.05$ vs. 0 h; ${ }^{* *} p<0.01$ vs. 0 h. 

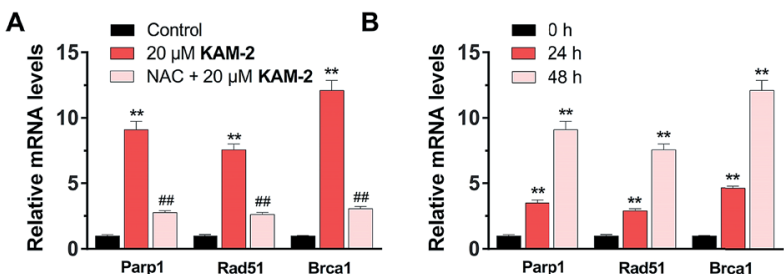

Fig. 9 The concentration- (A) and time-dependent (B) effects of 20 $\mu$ M KAM-2 on the expression DDR-related mRNA levels tested by realtime PCR. Mean $\pm \mathrm{SD}, n=3 .{ }^{* *} p<0.01 \mathrm{vs}$. control or 0 h treatment; $\# \#<0.01$ vs. $20 \mu$ M KAM-2 treatment.

Finally, the effects of KAM-2 on the expression of Parp1, Rad51 and Brca1 mRNAs were investigated in HL-60 cells. Realtime PCR assay confirmed that KAM-2 concentration (Fig. 9A) and time (Fig. 9B) dependently elevated the mRNA expression levels of Parp-1, Rad51 and Brca1. Importantly, NAC pretreatment mitigated the effects of KAM-2 on gene expression.

\section{Conclusions}

In summary, we for the first time present an $\alpha$-ketoamide scaffold to build up $\mathrm{H}_{2} \mathrm{O}_{2}$-activated prodrugs, using nitrogen mustard as the model drug. Our studies identified KAM-2 as a novel anticancer prodrug deserving further investigations. KAM-2 obviously inhibited the growth of different cancer cell lines with diminished cytotoxicity in normal PBMC cells. The $\mathrm{H}_{2} \mathrm{O}_{2}$-induced decomposition of KAM-2 was confirmed using various analytical methods. The nitrogen mustard released from KAM-2 exhibited DNA ICL ability, led to DNA damage in HL-60 cells, and increased the expression of DDR related proteins and mRNAs. Additional mechanism studies suggested that KAM-2 induced HL-60 apoptosis in a mitochondrial-dependent manner. In addition to the emerged boronbased $\mathrm{H}_{2} \mathrm{O}_{2}$-responsive prodrugs, our work showcases the establishment of a new platform for prodrug design inspired from analytical probes. Considering the close involvement of $\mathrm{H}_{2} \mathrm{O}_{2}$ in many pathological diseases, it is anticipated that our results will actively promote the development of both small molecule and nanoparticle-based agents in related fields.

\section{Conflicts of interest}

There are no conflicts to declare.

\section{Acknowledgements}

This work is supported by National Natural Science Foundation of China (21877052, 81602960), Natural Science Foundation of Jiangsu Province (BK20180030, BK20161028), and the Fundamental Research Funds for the Central Universities (JUSRP51712B).

\section{Notes and references}

1 J. Rautio, N. A. Meanwell, L. Di and M. J. Hageman, Nat. Rev. Drug Discovery, 2018, 17, 559.
2 S. H. Alamudi and Y. T. Chang, Chem. Commun., 2018, 54, 13641.

3 D. S. Folk and K. J. Franz, J. Am. Chem. Soc., 2010, 132, 4994.

4 N. Ueki, S. Lee, N. S. Sampson and M. J. Hayman, Nat. Commun., 2013, 4, 2735.

5 A. Tanaka, Y. Fukuoka, Y. Morimoto, T. Honjo, D. Koda, M. Goto and T. Maruyama, J. Am. Chem. Soc., 2015, 137, 770.

6 S. W. Chung, J. U. Choi, Y. S. Cho, H. R. Kim, T. H. Won, P. Dimitrion, O. C. Jeon, S. W. Kim, I. S. Kim, S. Y. Kim and Y. Byun, Adv. Sci., 2018, 5, 1800368.

7 S. Bakthavatsalam, M. L. Sleeper, A. Dharani, D. J. George, T. Zhang and K. J. Franz, Angew. Chem., Int. Ed., 2018, 57, 12780.

8 X. Li, Y. Hou, X. Meng, C. Ge, H. Ma, J. Li and J. Fang, Angew. Chem., Int. Ed., 2018, 57, 6141.

9 F. Kang, J. Zhu, J. Wu, T. Lv, H. Xiang, J. Tian, Y. Zhang and Z. Huang, Chem. Sci., 2018, 9, 6893.

10 S. B. Salunke, J. A. Malla and P. Talukdar, Angew. Chem., Int. Ed. Engl., 2019, 58, 5354.

11 P. Wei, L. Liu, Y. Wen, G. Zhao, F. Xue, W. Yuan, R. Li, Y. Zhong, M. Zhang and T. Yi, Angew. Chem., Int. Ed., 2019, 58, 4547.

12 R. Radi, Proc. Natl. Acad. Sci. U. S. A., 2018, 115, 5839.

13 B. D'Autreaux and M. B. Toledano, Nat. Rev. Mol. Cell Biol., 2007, 8, 813.

14 M. C. Chang, A. Pralle, E. Y. Isacoff and C. J. Chang, J. Am. Chem. Soc., 2004, 126, 15392.

15 E. W. Miller, A. E. Albers, A. Pralle, E. Y. Isacoff and C. J. Chang, J. Am. Chem. Soc., 2005, 127, 16652.

16 L. K. Charkoudian, D. M. Pham and K. J. Franz, J. Am. Chem. Soc., 2006, 128, 12424.

17 J. L. M. Jourden and S. M. Cohen, Angew. Chem., Int. Ed., 2010, 49, 6795.

18 Y. Kuang, K. Baakrishnan, V. Gandhi and X. Peng, J. Am. Chem. Soc., 2011, 133, 19278.

19 K. B. Daniel, J. L. M. Jourden, K. E. Negoescu and S. M. Cohen, J. Biol. Inorg Chem., 2011, 16, 313.

20 C. Perez, J.-P. Monserrat, Y. Chen and S. M. Cohen, Chem. Commun., 2015, 51, 7116.

21 C. K. Wang, J. Cheng, X. G. Liang, C. Tan, Q. Jiang, Y. Z. Hu, Y. M. Lu, K. Fukunaga, F. Han and X. Li, Theranostics, 2017, 7, 3803.

22 C. Tapeinos and A. Pandit, Adv. Mater., 2016, 28, 5553.

23 G. Saravanakumar, J. Kim and W. J. Kim, Adv. Sci., 2017, 4, 1600124.

24 C. Achilli, A. Ciana, M. Fagnoni, C. Balduini and G. Minetti, Cent. Eur. J. Chem., 2013, 11, 137.

25 Y. Furikado, T. Nagahata, T. Okamoto, T. Sugaya, S. Iwatsuki, M. Inamo, H. D. Takagi, A. Odani and K. Ishihara, Chem.-Eur. J., 2014, 20, 13194.

26 C. Gao, Y. Tian, R. Zhang, J. Jing and X. Zhang, Anal. Chem., 2017, 89, 12945.

27 X. Xie, X. Yang, T. Wu, Y. Li, M. Li, Q. Tan, X. Wang and B. Tang, Anal. Chem., 2016, 88, 8019.

28 P. Gao, W. Pan, N. Li and B. Tang, Chem. Sci., 2019, 10, 6035. 29 S. Cao, Y. Wang and X. Peng, Chem.-Eur. J., 2012, 18, 3850. 
30 W. Chen, K. Balakrishnan, Y. Kuang, Y. Han, M. Fu, V. Gandhi and X. Peng, J. Med. Chem., 2014, 57, 4498.

31 W. Chen, H. Fan, K. Balakrishnan, Y. Wang, H. Sun, Y. Fan, V. Gandhi, L. A. Arnold and X. Peng, J. Med. Chem., 2018, 61, 9132.

32 A. Alouane, R. Labruere, T. Le Saux, F. Schmidt and L. Jullien, Angew. Chem., Int. Ed., 2015, 54, 7492.

33 R. Kumar, J. Han, H. J. Lim, W. X. Ren, J. Y. Lim, J. H. Kim and J. S. Kim, J. Am. Chem. Soc., 2014, 136, 17836.

34 H. W. Liu, X. X. Hu, K. Li, Y. Liu, Q. Rong, L. Zhu, L. Yuan, F. L. Qu, X. B. Zhang and W. Tan, Chem. Sci., 2017, 8, 7689.

35 H. Hagen, P. Marzenell, E. Jentzsch, F. Wenz, M. R. Veldwijk and A. Mokhir, J. Med. Chem., 2012, 55, 924.

36 J. Noh, B. Kwon, E. Han, M. Park, W. Yang, W. Cho, W. Yoo, G. Khang and D. Lee, Nat. Commun., 2015, 6, 6907.

37 C. Q. Luo, Y. X. Zhou, T. J. Zhou, L. Xing, P. F. Cui, M. Sun, L. Jin, N. Lu and H. L. Jiang, J. Controlled Release, 2018, 274, 56.
38 T. P. Szatrowski and C. F. Nathan, Cancer Res., 1991, 51, 794. 39 Z. Can, A. Uzer, K. Turkekul, E. Ercag and R. Apak, Anal. Chem., 2015, 87, 9589.

40 T. B. Zanoni, F. Hudari, A. Munnia, M. Peluso, R. W. Godschalk, M. V. Zanoni, G. J. den Hartog, A. Bast, S. B. Barros, S. S. Maria-Engler, G. J. Hageman and D. P. de Oliveira, Toxicol. Lett., 2015, 239, 194.

41 R. K. Singh, S. Kumar, D. N. Prasad and T. R. Bhardwaj, Eur. J. Med. Chem., 2018, 151, 401.

42 J. J. Tepe and R. M. Williams, J. Am. Chem. Soc., 1999, 121, 2951.

43 E. P. Rogakou, D. R. Pilch, A. H. Orr, V. S. Ivanova and W. M. Bonner, J. Biol. Chem., 1998, 273, 5858.

44 S. Ganesan and A. F. Keating, Toxicol. Appl. Pharmacol., 2015, 282, 252. 